\title{
Behavior of Multi-Story Building With and Without Shear Wall Under the Effect Wind Loads
}

\author{
Mustafa Wassef Abdulmajeed \\ Assistant Teacher. Building and Construction Engineering Department, Al-ISRAA University, Baghdad, Iraq
}

\begin{abstract}
Shear walls are specially designed structural walls that are incorporated in buildings to resist lateral forces that are created in the plane of wall due to wind, earthquake and flexural members. This paper presents the study and comparison of the distinction between the wind behaviors of buildings with and while not shear wall victimization Staad professional.
\end{abstract}

Keywords, Shear wall, STAAD PRO, Wind behavior

DOI: $10.7176 /$ CER/11-2-05

Publication date:March $31^{\text {st }} 2019$

\section{Introduction}

The high rise building represent the optimum like areas particularly in dense and expensive areas, together with excellence in execution and esthetically conjointly different considerations that everyone over the globe. Some high-rise buildings regarding the globe see

Figure (1.1)

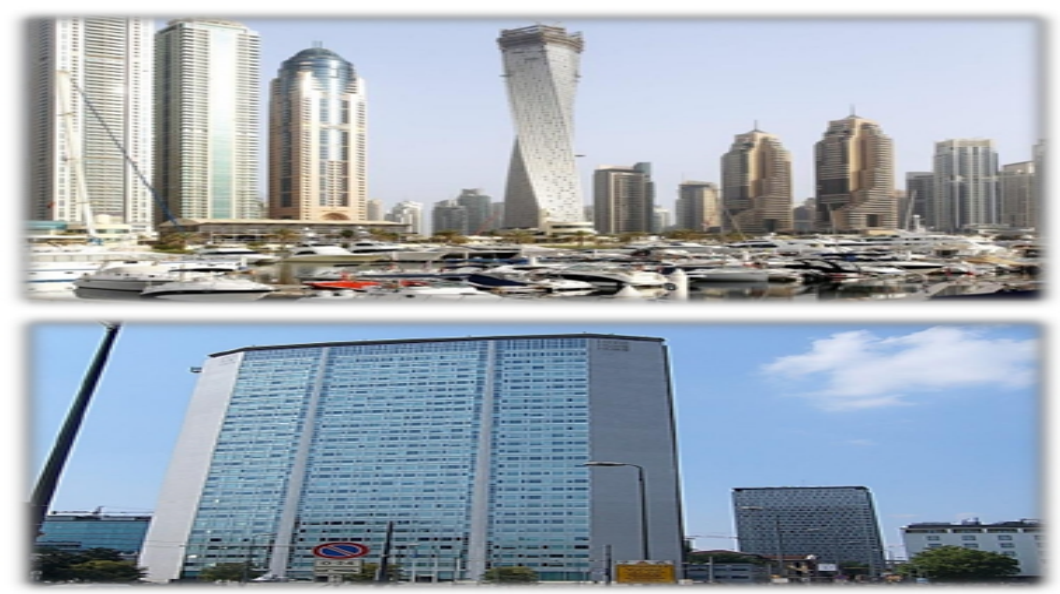

Figure 1.1: some high-rise buildings about the world

\subsection{Structural Systems for Tall Buildings}

The following classification is planned for the structural systems of tall buildings for all the categories specifically, steel buildings, ferroconcrete buildings, and composite buildings.[5]:

1. Rigid frame systems

2. Braced frame and shear-walled frame systems

3. Stabilizer systems

4. Framed-tube systems

5. Braced-tube systems

6. Bundled-tube systems

\subsubsection{Rigid Frame Systems}

Rigid frame systems are utilized in both steel and reinforced concrete construction. Rigid frame systems for resisting lateral and vertical loads have long been accepted for the design of the buildings. Rigid framing, namely moment framing, is based on the fact that beam-to-column connections have enough rigidity to hold the nearly unchanged original angles between intersecting components. Owing to the natural monolithically behavior, hence the inherent stiffness of the joist, rigid framing is ideally suitable for reinforced concrete buildings [5].

For a rigid frame the strength and stiffness are proportional to the dimension of the beam and the column dimension, and inversely proportional to the column spacing. , Especially for the buildings constructed in seismic zones, a special attention should be given to the design and detailing of joints, since rigid frames are more ductile and less vulnerable to severe earthquakes when compared to steel braced or shear- walled structures. (Fig.1.2) 


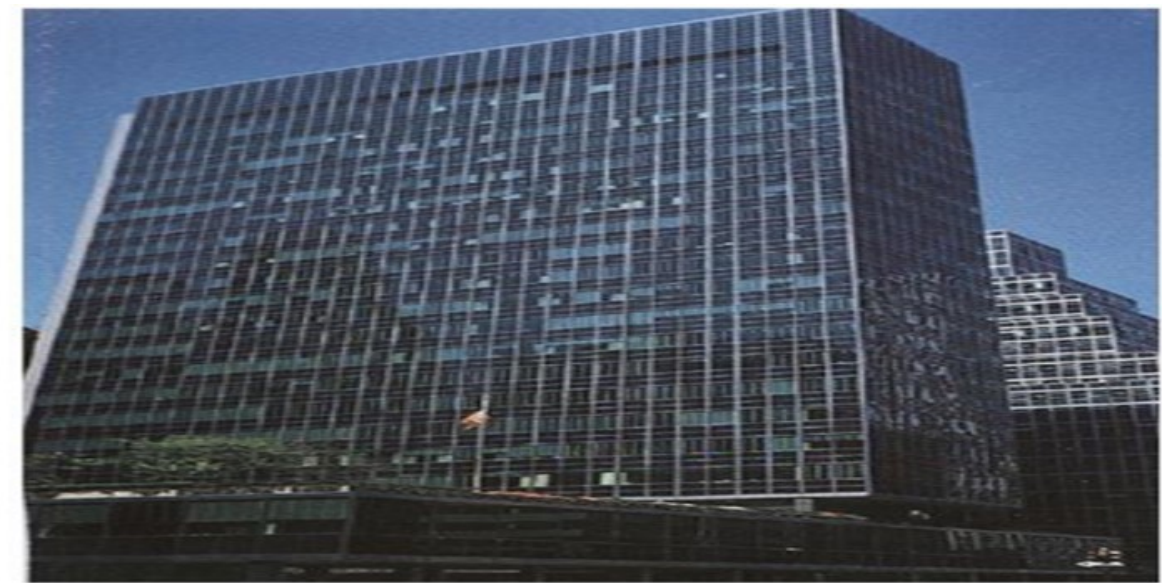

Figure. 1.2: Rigid Frame Systems

\subsubsection{Braced Frame and Shear-Walled Frame Systems}

Rigid frame systems are not efficient for buildings taller than 30 stories, because lateral deflection due to the bending of columns causes the drift to be too large. On the other hand, steel bracing or shear walls with or without rigid frame (brace systems and shear wall systems), increases the total rigidity of the building and the resulting system is named as braced frame or shear-walled frame system. Namely, systems composed of steel bracing or shear walls alone, or interacting with the rigid frames can be accepted as an improvement of the rigid frame system. These systems are stiffer when compared to the rigid frame system, and can be used for buildings over 30 stories, but mostly applicable for buildings about 50 stories in height. .[5]

\subsubsection{Braced Frame Systems}

Braced frame systems are utilized in steel construction. This system is a highly efficient and economical system for resisting horizontal loading, and attempts to improve the effectiveness of a rigid frame by almost eliminating the bending of columns and girders, by the help of additional bracing. It behaves structurally like a vertical gravity loads, and diagonal bracing components so that the total set of members forms a vertical cantilever truss to resist the horizontal loading.

\subsubsection{Shear-Walled Frame Systems}

Resist lateral wind and seismic loads acting on a building and transmitted to them by the floor diaphragms. Shear walls are generally parts of the elevator and service corps, and frames to create a stiffer and stronger structure. These elements can have various shapes such as, circular, curvilinear, oval, box-like, triangular, or rectilinear. This system structurally behaves like a concrete building with shear walls resisting all the lateral loads. (Fig.1.3)

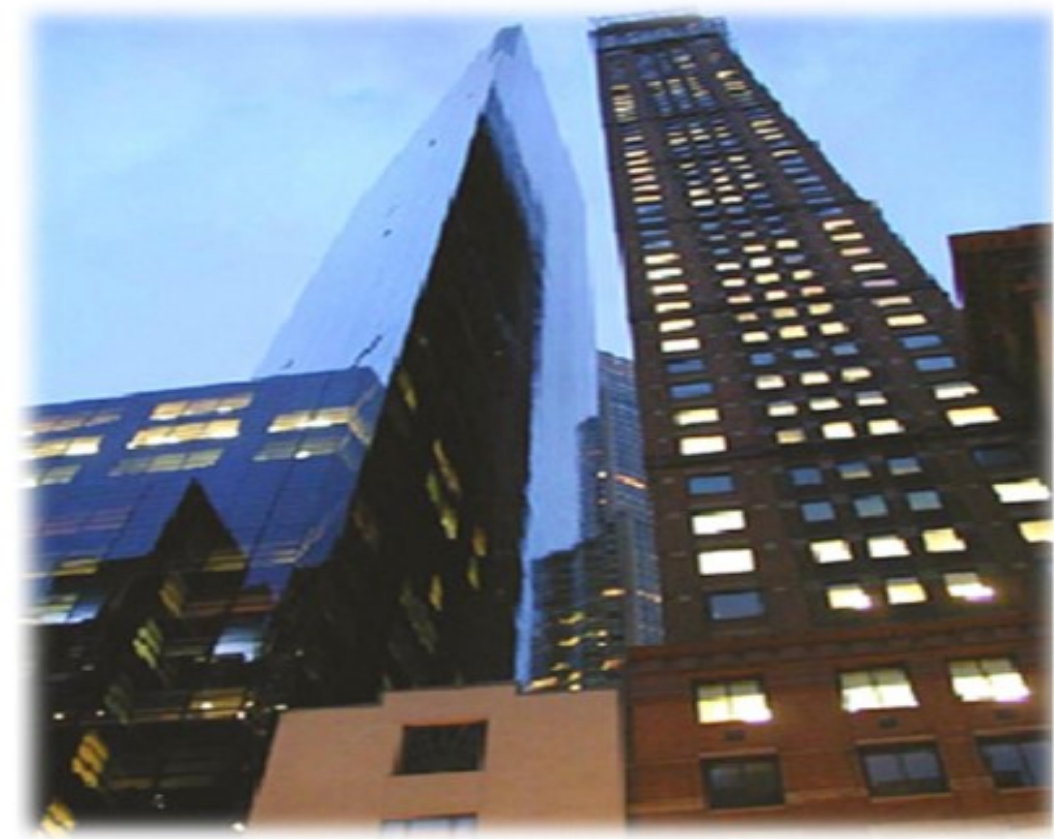

Figure. 1.3 Buildings with Shear Wall 


\subsection{Tall building codes}

- ASCE/SEI 7-10

- $(2006-2009)$ IBC

- $\quad$ ACI $318-05 / 08$

المسودة الاولية لمدونة الزلزال العر اقية (م.ب.ع ) .

\subsection{Difference between Law Rise Buildings and Tall Buildings}

A tall- building is defined as a building 35 meters or greater in height, which is divided at regular intervals into occupiable levels. To be considered a high-rise building, an edifice must be based on solid ground and fabricated along its full height.[3]The cut-off between tall and low buildings is 35 meters. A low-rise building is defined as any occupy able building which is divided at regular intervals into occupiable levels and which is lower than a high-rise, i.e., lower than 35 meters. To be considered a low-rise building, an edifice must be based on solid ground and fabricated along its full height and have at least one floor above the ground [3].see (fig1.4) for law rise and tall building difference.

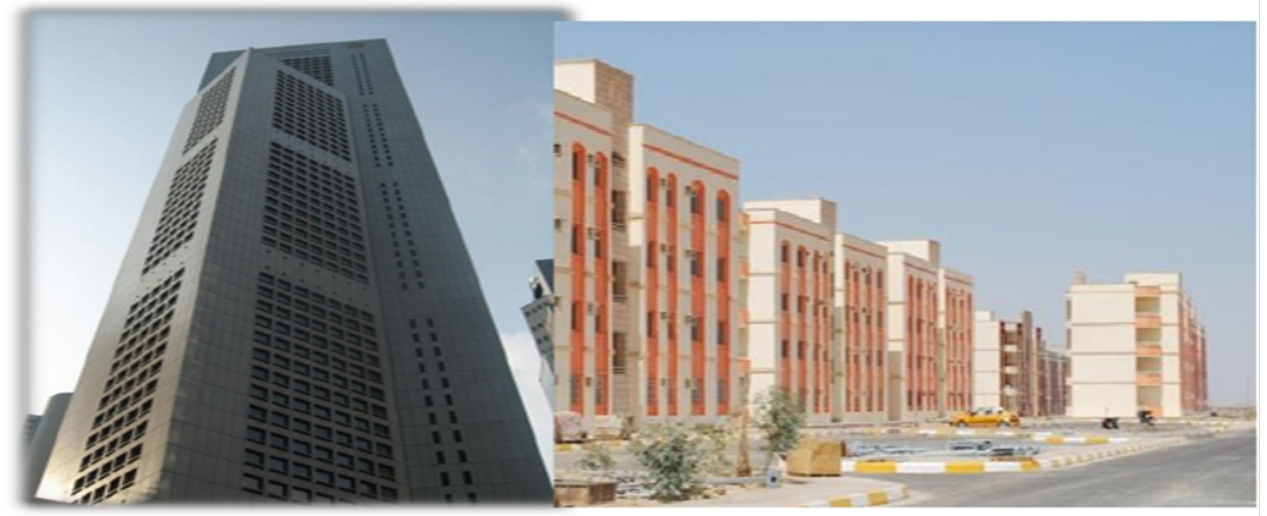

Figure 1.4: Tall and law buildings

\section{Loads on High Rise Buildings}

\subsection{Loads}

Structural members must be designed to support specific loads. Loads are those forces for which a given structure should be proportioned. In general, loads may be classified as dead or live.

\subsection{1dead Load}

Dead loads consist of the weight of all materials of construction incorporated into the building including but not limited to walls, floors, roofs, ceilings, stairways, built-in partitions, finishes, cladding and other similarly incorporated architectural and structural items, and fixed service equipment including the weight of ranes.[1]

\subsubsection{Live Load}

Live loads are those loads produced by the use and occupancy of the building or other structure and do not include construction or environmental loads such as wind load, snow load, rain load, earthquake load, flood load, or dead load. Live loads on a roof are those produced:

(1) During maintenance by workers, equipment, and materials

(2) During the life of the structure by movable objects such as planters and by people.

- The ACI Code does not specify loads on structures; however, IBC-2012 and the American National Standards Institute (ANSI) [5] prescribe occupancy loads on different types of buildings. Some typical values are shown in Table 2.1. Table 2.2 shows the density of various materials.

- The live loads used in the design of buildings and other structures shall be the maximum loads expected by the intended use or occupancy but shall in no case be less than the minimum uniformly distributed unit loads required by Table (2-1). 
Table 2. 1 Typical Uniformly Distributed Design live Loads

\begin{tabular}{|c|c|}
\hline Occupancy or Use & $\begin{array}{l}\text { Uniform pst } \\
\left(0 \times \mathrm{m}^{2}\right)\end{array}$ \\
\hline \multicolumn{2}{|l|}{ Apartments (see residential) } \\
\hline $\begin{array}{l}\text { Access foor systems } \\
\text { Office use } \\
\text { Computer use }\end{array}$ & $\begin{array}{c}50(2.4) \\
100(4.79)\end{array}$ \\
\hline Armories and drill rooms & 150 (7.18) \\
\hline $\begin{array}{l}\text { Assembly areas and theaters } \\
\text { Fixed seats (fastened to floor) } \\
\text { Lobbies } \\
\text { Movable seats } \\
\text { Platfoms (assembly) } \\
\text { Stage floors }\end{array}$ & $\begin{array}{c}60(2.87) \\
100(4.79) \\
100(4.79) \\
100(4.79) \\
150(7.18)\end{array}$ \\
\hline $\begin{array}{l}\text { Balconies (exterior) } \\
\text { On one- and two-family residences only, and not exceeding } 100 \mathrm{ft}^{2}\left(9.3 \mathrm{~m}^{2}\right)\end{array}$ & $\begin{array}{l}100(4.79) \\
60(2.87)\end{array}$ \\
\hline Bowling alleys, poolrooms, and similar recreational areas & 75 (3.59) \\
\hline Catwalks for maintenance access & $40(1.92)$ \\
\hline $\begin{array}{l}\text { Corridors } \\
\text { First floor } \\
\text { Other floors, same as occupancy served except as indicated }\end{array}$ & $100(4.79)$ \\
\hline Dance halls and ballrooms & $100(4.79)$ \\
\hline \multicolumn{2}{|l|}{$\begin{array}{l}\text { Decks (patio and roof) } \\
\text { Same as area served, or for the type of occupancy accommodated }\end{array}$} \\
\hline Dining rooms and restaurants & $100(4.79)$ \\
\hline \multicolumn{2}{|l|}{ Dwellings (see residential) } \\
\hline \multicolumn{2}{|l|}{ Elevator machine room grating (on area of 4 in. $^{2}\left(2580 \mathrm{~mm}^{2}\right)$ ) } \\
\hline \multicolumn{2}{|l|}{ Finish light floor plate construction (on area of 1 in. $^{2}\left(645 \mathrm{~mm}^{2}\right)$ ) } \\
\hline $\begin{array}{l}\text { Fire escapes } \\
\text { On single-family dwellings only }\end{array}$ & $\begin{array}{l}100(4.79) \\
40(1.92)\end{array}$ \\
\hline \multicolumn{2}{|l|}{ Fixed ladders } \\
\hline $\begin{array}{l}\text { Garages (passenger vehicles only) } \\
\text { Trucks and buses }\end{array}$ & $40(1.92)$ \\
\hline
\end{tabular}


Table 2 .1 Typical Uniformly Distributed Design live Loads

\begin{tabular}{|c|c|}
\hline Occupancy or Use & $\begin{array}{l}\text { Unitorm pst } \\
\left(\mathbf{c k N} / \mathbf{m}^{2}\right)\end{array}$ \\
\hline \multicolumn{2}{|l|}{ Grandstands (see stadium and arena bleachers) } \\
\hline Gymasiums, main floors, and balconies & $100(4.79)$. Note (4) \\
\hline Handrails, guardrails, and grab bars & See $s$ \\
\hline $\begin{array}{l}\text { Hospitals } \\
\text { Operating rooms, laboratories } \\
\text { Private rooms } \\
\text { Wards } \\
\text { Corridors above first floor }\end{array}$ & $\begin{array}{l}60(2.87) \\
40(1.92) \\
40(1.92) \\
80(3.83)\end{array}$ \\
\hline \multicolumn{2}{|l|}{ Hotels (see residential) } \\
\hline $\begin{array}{l}\text { Libraries } \\
\text { Reading rooms } \\
\text { Stack rooms } \\
\text { Corridors above first floor }\end{array}$ & $\begin{array}{c}60(2.87) \\
150(7.18) \text { Note (3) } \\
80(3.83)\end{array}$ \\
\hline $\begin{array}{l}\text { Manufacturing } \\
\text { Light } \\
\text { Heavy }\end{array}$ & $\begin{array}{c}125(6.00) \\
250(11.97)\end{array}$ \\
\hline Marquees and canopies & $75(3.59)$ \\
\hline $\begin{array}{l}\text { Office buildings } \\
\text { File and computer rooms shall be designed for heavier } \\
\text { loads based on anticipated occupancy } \\
\text { Lobbies and first floor corridors } \\
\text { Orfices } \\
\text { Corridors above first floor }\end{array}$ & $\begin{array}{l}100(4.79) \\
50(2.40) \\
80(3.83)\end{array}$ \\
\hline $\begin{array}{l}\text { Penal institutions } \\
\text { Cell blocks } \\
\text { Corridors }\end{array}$ & $\begin{array}{l}40(1.92) \\
100(4.79)\end{array}$ \\
\hline $\begin{array}{l}\text { Residential } \\
\text { Dwellings (one- and two-family) } \\
\text { Uninhabitable attics without storage } \\
\text { Uninhabitable attics with storage } \\
\text { Habitable attics and sleeping areas } \\
\text { All other areas except stairs and balconies } \\
\text { Hotels and multifamily houses } \\
\text { Private rooms and corridors serving them } \\
\text { Public rooms and corridors serving them }\end{array}$ & $\begin{array}{l}10(0.48) \\
20(0.96) \\
30(1.44) \\
40(1.92) \\
40(1.92) \\
100(4.79)\end{array}$ \\
\hline Reviewing stands, grandstands, and bleachers & 100 (4.79), Note (4) \\
\hline
\end{tabular}


Table 2. 2 Density of Various Materials

\begin{tabular}{|c|c|c|}
\hline \multirow[b]{2}{*}{ Material } & \multicolumn{2}{|c|}{ Density } \\
\hline & $\mathrm{lb} / \mathrm{ft}^{3}$ & $\mathrm{~kg} / \mathrm{m}^{3}$ \\
\hline \multicolumn{3}{|l|}{ Building materials } \\
\hline Bricks & 120 & 1,924 \\
\hline Cement, portland, loose & 90 & 1,443 \\
\hline Cement, portland, set & 183 & 2,933 \\
\hline Earth, dry, packed & 95 & 1,523 \\
\hline Sand or gravel, dry, packed & $100-120$ & $1,600-1,924$ \\
\hline Sand or gravel, wet & $118-120$ & $1,892-1,924$ \\
\hline \multicolumn{3}{|l|}{ Liquids } \\
\hline Oils & 58 & 930 \\
\hline Water (at $4^{\circ} \mathrm{C}$ ) & 62.4 & 1,000 \\
\hline Ice & 56 & 898 \\
\hline \multicolumn{3}{|l|}{ Metals and minerals } \\
\hline Aluminum & 165 & 2,645 \\
\hline Copper & 556 & 8,913 \\
\hline Iron & 450 & 7,214 \\
\hline Lead & 710 & 11,380 \\
\hline Steel, rolled & 490 & 7,855 \\
\hline Limestone or marble & 165 & 2,645 \\
\hline Sandstone & 147 & 2,356 \\
\hline Shale or slate & 175 & 2,805 \\
\hline \multicolumn{3}{|l|}{ Normal-weight concrete } \\
\hline Plain & 145 & 2,324 \\
\hline Reinforced or prestressed & 150 & 2,405 \\
\hline
\end{tabular}

\subsection{Wind Load}

Buildings and their components are to be designed to withstand the code- Specified wind loads. Calculating wind loads is important in design of the Wind force-resisting system, including structural members, components and cladding, against shear, sliding, overturning and uplift actions. See fig 2.1 


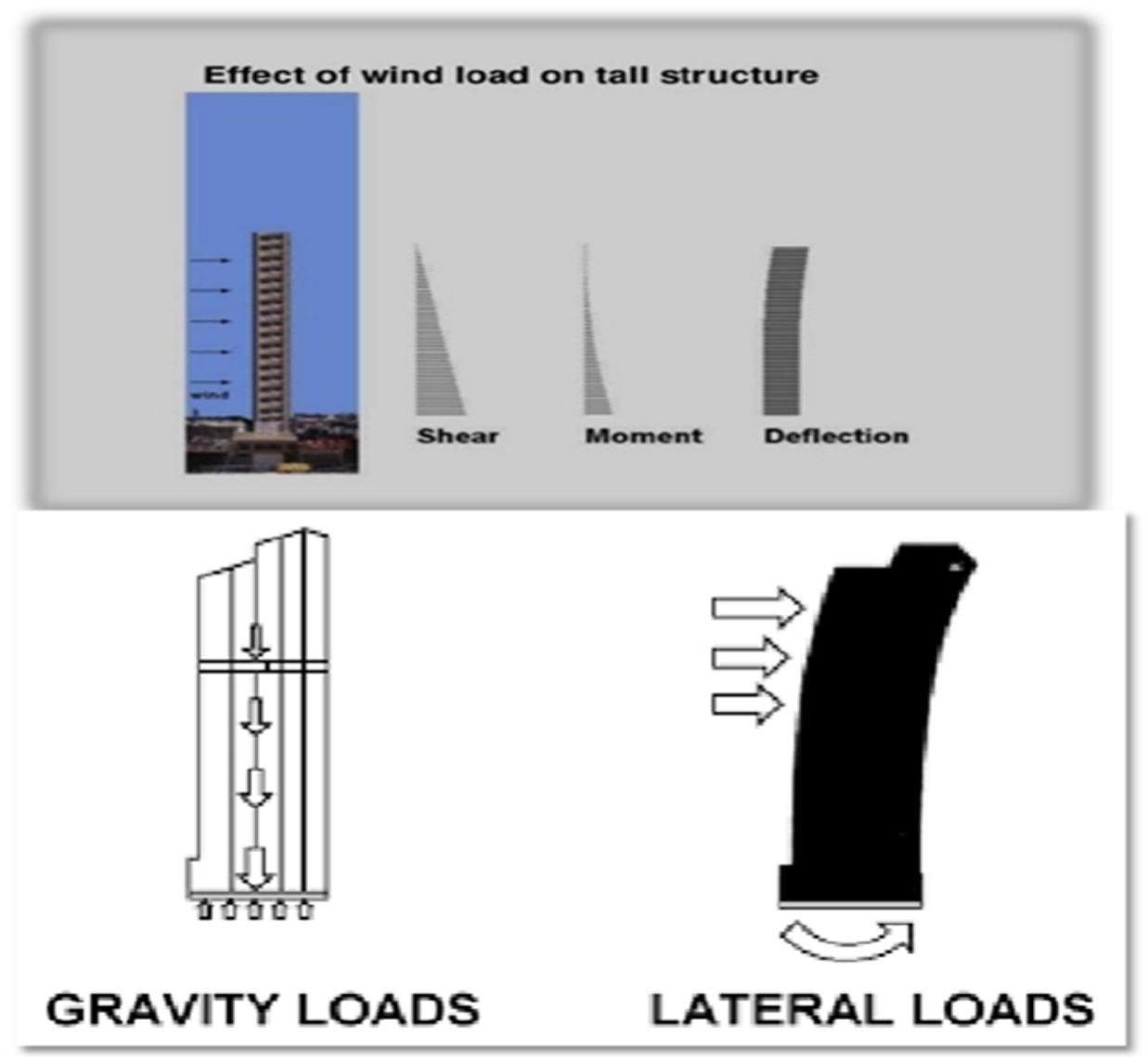

\subsubsection{Methods of Determination Wind Load}

Figure 2.1 effect of wind load on building

The design wind loads for buildings and other structures shall be Determined according to one of the following procedures [ASCE7-10]:

(1) Method - Simplified procedure for low-rise simple diaphragm buildings.

(2) Method - Analytical procedure for regular shaped building and structures.

\subsubsection{Method - Simplified Procedure}

The simplified procedure is used for determining and applying wind pressures in the design of simple diaphragm buildings with flat, gabled, and hipped roofs and having a mean roof height not exceeding the least horizontal dimension or 60 feet $(18.3 \mathrm{~m})$, whichever is less, and subject to additional limitations.

\subsubsection{Method - Analytical Procedur}

Wind loads for buildings and structures that do not satisfy the conditions for using the simplified procedure can be calculated using the analytical procedure provided that it is a regular shaped building or structure, and it does not have response characteristics making it subject to a cross-wind loading, vortex shedding, instability due to galloping or flutter, or does not have a site location that require special consideration. [ASCE7-10]

Method 1 can't use for determination of wind load due to building height $(64 \mathrm{~m})$ and it use for building with law rise $(<18.3 \mathrm{~m})$ so we will be use method 2 for determine wind load.

\subsection{Procedure for Determined Wind Load}

\subsubsection{Determine Velocity Pressure}

Velocity pressure, qz, evaluated at height $\mathrm{z}$ shall be calculated by the following equation [ASCE7-10]:-

Where:-

$\mathrm{qz}=$ velocity pressure

$\mathrm{Kd}=$ wind directionality factor

$\mathrm{Kz}=$ velocity pressure exposure coefficient

$\mathrm{Kzt}=$ topographic factor defined

$\mathrm{V}=$ basic wind speed

2.3.1.1. Determine Kd

Kd find from Table (2-3). 
Table (2-3)

\begin{tabular}{|c|c|}
\hline Structure Type & Directionality Factor $\mathbf{K}_{\mathrm{d}^{*}}$ \\
\hline $\begin{array}{l}\text { Buildings } \\
\text { Main Wind Force Resisting System } \\
\text { Components and Cladding }\end{array}$ & $\begin{array}{l}0.85 \\
0.85\end{array}$ \\
\hline Arehed Roofs & 0.85 \\
\hline $\begin{array}{l}\text { Chimneys, Tanks, and Similar Structures } \\
\text { Square } \\
\text { Hexagonal } \\
\text { Round }\end{array}$ & $\begin{array}{l}0.90 \\
0.95 \\
0.95\end{array}$ \\
\hline $\begin{array}{l}\text { Solid Freestanding Walls and Solid } \\
\text { Freestanding and Attached Signs }\end{array}$ & 0.85 \\
\hline Open Signs and Lattice Framework & 0.85 \\
\hline $\begin{array}{l}\text { Trussed Towers } \\
\text { Triangular, square, rectangular } \\
\text { All other cross sections }\end{array}$ & $\begin{array}{l}0.85 \\
0.95\end{array}$ \\
\hline
\end{tabular}

\subsubsection{Find Kzt}

Kzt find from

$\mathrm{Kzt}=(1+\mathrm{K} 1 \mathrm{~K} 2 \mathrm{~K} 3) 2$

Where:-

$\mathrm{K} 1, \mathrm{~K} 2$, and $\mathrm{K} 3$ are given in Table (2-4) shown below. If site conditions and Locations of structures do not meet all the conditions specified in

Table (2-4). then Kzt $=1.0$.

Table (2-4)

\begin{tabular}{|c|c|c|c|c|c|c|}
\hline \multicolumn{7}{|c|}{ Parameters for Speed-Up Over Hills and Escarpments } \\
\hline \multirow{3}{*}{ Hill Shape } & \multirow{2}{*}{\multicolumn{3}{|c|}{$\begin{array}{l}\mathbf{K}_{\mathrm{t}} /\left(\mathbf{H} / \mathbf{L}_{\mathrm{Q}}\right) \\
\text { Exposure }\end{array}$}} & \multirow{3}{*}{$\boldsymbol{\gamma}$} & \multicolumn{2}{|c|}{$\mu$} \\
\hline & & & & & \multirow{2}{*}{$\begin{array}{l}\text { Upwind } \\
\text { of Crest }\end{array}$} & \multirow{2}{*}{$\begin{array}{c}\text { Downwind } \\
\text { of Crest }\end{array}$} \\
\hline & $\mathbf{B}$ & $\mathbf{C}$ & $\mathbf{D}$ & & & \\
\hline $\begin{array}{l}\text { 2-dimensional ridges } \\
\text { (or valleys with negative } \\
\mathrm{H} \text { in } \mathrm{K}_{1} /\left(\mathrm{H} / \mathrm{L}_{\mathrm{b}}\right)\end{array}$ & 1.30 & 1.45 & 1.55 & 3 & 1.5 & 1.5 \\
\hline 2-dimensional escarpments & 0.75 & 0.85 & 0.95 & 2.5 & 1.5 & 4 \\
\hline 3-dimensional axisym. hill & 0.95 & 1.05 & 1.15 & 4 & 1.5 & 1.5 \\
\hline
\end{tabular}
Notes:

1. For values of $H / L_{3}, x / L_{t}$ and $z / L_{2}$ other than those shown, linear interpolation is permitted.

2. For $H / L_{-}>0.5$, assume $H / L_{\mathbf{a}}=0.5$ for evaluating $K_{2}$ and substitute $2 \mathrm{H}$ for $\mathrm{L}_{0}$ for evaluating $K_{2}$ and $\mathrm{K}_{3}$.

3. Multipliers are based on the assumption that wind approaches the bill or escarpment along the direction of maximum slope.

4. Notation:

H: Height of hill or escarpment relative to the upwind terrain, in feet (meters).

$L_{h}$ : Distance upwind of crest to where the difference in ground elevation is half the height of hill or escarpment, in feet (meters).

$K_{1}$ : Factor to account for shape of topographic feature and maximum speed-up effect.

$\mathrm{K}_{2}$ : Factor to account for reduction in speed-up with distance upwind or downwind of crest

$\mathrm{K}_{3}$ : Factor to account for reduction in speed-up with height above local terrain.

$x$ : Distance (upwind or downwind) from the crest to the building site, in feet (meters).

z. Height above ground surface at building site, in feet (meters).

$\mu$ : Horizontal attenuation factor.

$\gamma$ Height attenuation factor. 


\subsubsection{Find $\mathrm{Kz}$}

$\mathrm{Kz}$ find from equation below :-

1 - The velocity pressure exposure coefficient $\mathrm{Kz}$ may be determine from

the following formula or from the Table (2-5):-

For $15 \mathrm{ft} . \leq \mathrm{z} \leq \mathrm{zg}$

$\mathrm{Kz}=2.01(\mathrm{z} / \mathrm{zg}) 2 / \alpha$

$$
K_{2}=\left(1-\frac{|x|}{\mu L_{h}}\right)
$$

For $\mathrm{z}<15 \mathrm{ft}$.

$\mathrm{kz}=2.01(15 / \mathrm{zg}) 2 / \alpha$

$K_{3}=e^{-\gamma 2 L_{h}}$

$2-\alpha$ and $z g$ in Table (2-6)

3 - Linear interpolation for intermediate values of height $\mathrm{z}$ is acceptable

Table 2.5 velocity pressure exposure coefficients, $\mathrm{Kz}$ and $\mathrm{Kh}$

\begin{tabular}{|c|c|c|c|c|}
\hline \multirow{2}{*}{\multicolumn{2}{|c|}{$\begin{array}{l}\text { Height above } \\
\text { ground level, }\end{array}$}} & \multicolumn{3}{|c|}{ Exposure } \\
\hline & & \multirow{2}{*}{$\mathbf{B}$} & \multirow{2}{*}{ C } & \multirow{2}{*}{$\mathbf{D}$} \\
\hline rt & (m) & & & \\
\hline D-15 & $(0-4.6)$ & 0.57 & 0.85 & 1.03 \\
\hline 20 & $(5.1)$ & 0.62 & 0.90 & 1.08 \\
\hline 25 & $(7.6)$ & 0.66 & 0.94 & 1.12 \\
\hline 30 & $(9.1)$ & 0.70 & 0.98 & \\
\hline 40 & $(122)$ & 0.76 & 1.04 & 1.22 \\
\hline 50 & $(15.2)$ & 0.81 & 1.09 & 1.27 \\
\hline 60 & (18) & 0.85 & 1.13 & 1.31 \\
\hline 70 & $(21,3)$ & 0.89 & 1.17 & 1.34 \\
\hline 80 & $(2-4.4)$ & 0.93 & 1.21 & 1.38 \\
\hline 50 & $(27.4)$ & 0.96 & 1.24 & $\frac{1.40}{1.40}$ \\
\hline 100 & $(30.5)$ & 0.99 & 1.26 & 1.43 \\
\hline 120 & $(3.6 .6)$ & 1.04 & 1.31 & \\
\hline 140 & $(427)$ & 1.09 & 1.36 & \\
\hline 160 & $(48.8)$ & 1.13 & 1.39 & 1.55 \\
\hline 180 & $(5.4 .9)$ & 1.17 & 1.43 & 1.58 \\
\hline 200 & $(61.0)$ & 1.20 & 1.46 & 1.61 \\
\hline 250 & $(76.2)$ & 1.28 & 1.53 & 1.68 \\
\hline 300 & $(91.4)$ & 1.35 & 1.59 & 1.73 \\
\hline 350 & $(1067)$ & 141 & 1. 64 & 1.78 \\
\hline 400 & $(121.9)$ & 1.47 & 1.69 & 1.82 \\
\hline 450 & $(1372)$ & 1.52 & 1.73 & 1.36 \\
\hline 500 & $(152,4)$ & 1.56 & 1.77 & \\
\hline
\end{tabular}

Table 2.6

\begin{tabular}{|c|c|c|c|c|c|c|c|c|c|c|}
\hline \multirow{2}{*}{ Exposure } & $\boldsymbol{\alpha}$ & $\mathbf{z}_{\mathbf{z}}(\mathrm{m})$ & $\hat{\boldsymbol{\alpha}}$ & $\hat{\boldsymbol{b}}$ & $\overline{\boldsymbol{a}}$ & $\overline{\boldsymbol{b}}$ & $\mathrm{e}$ & $\ell(\mathrm{m})$ & $\bar{\epsilon}$ & $\mathrm{z}_{\min }(\mathrm{m})^{s}$ \\
\hline B & 7.0 & 365.76 & $1 / 7$ & 0.84 & $1 / 4.0$ & 0.45 & 0.30 & 97.54 & $1 / 3.0$ & 9.14 \\
\hline C & 9.5 & 274.32 & $1 / 9.5$ & 1.00 & $1 / 6.5$ & 0.65 & 0.20 & 152.4 & $1 / 5.0$ & 4.57 \\
\hline D & 11.5 & 213.36 & $1 / 11.5$ & 1.07 & $1 / 9.0$ & 0.80 & 0.15 & 198.12 & $1 / 8.0$ & 2.13 \\
\hline
\end{tabular}

\subsubsection{Find $V$}

Basic wind speed From Iraqi code by using wind map in (figure 2.2)

below المسودة الاولية لمدونة الزلز ال العراقية (م.ب.ع)

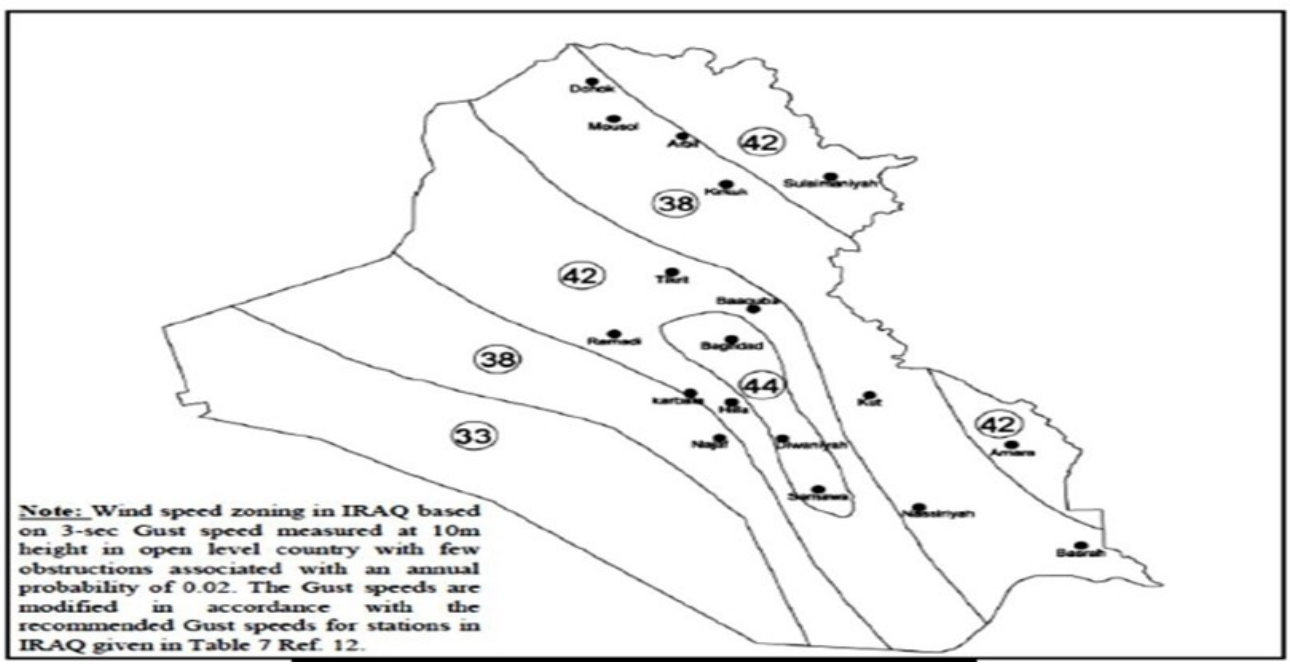

Figure 2.2 wind speed zoning in Iraq 


\subsubsection{Determine the Design Wind Pressure $(P)$ or Design Wind Load $(F)$}

The design wind load pressure is given by following equation:-
$\mathrm{P}=\mathrm{qz}$ G Cp - qi (GCpi)
$(\mathrm{N} / \mathrm{m} 2)$

Where:-

$\mathrm{q}=\mathrm{qz}$ for windward walls evaluated at height $\mathrm{z}$ above the ground $\mathrm{z}$.

$\mathrm{q}=\mathrm{qh}$ for leeward walls, sidewalls, and roofs, evaluated at height $\mathrm{h}$.

$\mathrm{qi}=\mathrm{qh}$ for windward walls, side walls, leeward walls, and roofs of enclosed buildings and for negative internal pressure evaluation in partially enclosed

$\mathrm{G}=$ gust-effect factor.

$\mathrm{Cp}=$ external pressure coefficient from.

( GCpi) = internal pressure coefficient from.

\subsubsection{Find $G$}

The gust-effect factor for a rigid building or other structure is permitted to be taken as 0.85 .

\subsubsection{Find Cp}

Cp find from Table 2.7

Table 2.7

\begin{tabular}{|l|c|c|c|}
\hline \multicolumn{3}{|c|}{ Wall Pressure Coefficients, $\boldsymbol{C}_{\mathbf{p}}$} \\
\hline Surface & $\mathbf{L}$. & $\mathbf{C}_{\mathbf{p}}$ & Use WVIth \\
\hline Windward Wall & All values & 0.8 & $\mathrm{q}_{\mathbf{z}}$ \\
\hline \multirow{3}{*}{ Leeward Wall } & $\mathbf{0}-\mathbf{1}$ & -0.5 & \multirow{2}{*}{$\mathrm{q}_{\mathrm{h}}$} \\
& 2 & -0.3 & \\
\hline Side Wall & $\geq 4$ & -0.2 & $\mathrm{q}_{\mathrm{h}}$ \\
\cline { 2 - 4 } & All values & -0.7 & \\
\hline
\end{tabular}

\section{Case Studies}

\subsection{Introduction}

Building engineered with structural walls are usually stiffer than framed structures reducing the possibility of excessive deformations and hence damage. The necessary strength to avoid structural damage under wind load can be achieved by providing a properly detailed longitudinal and transverse reinforcement. by adopting special detailing measures, depending ductile response can be achieved under major earthquakes.

Lateral forces, that is, the forces applied horizontally to a structural derived from winds or earthquakes cause shear and overturning moments in walls. the shear forces tend to tear the wall just as if you had a piece of paper attached to a frame and changed the frames shape from a rectangular to parallelogram. this changing of shape is generally referred as racking. at the ends of shear walls, there is a tendency for the wall to be lifted up at the end where the lateral force is applied.

\subsection{Description of the Structure}

The structures, used for the analyses, are assumed to be serving as school buildings. The detailed descriptions of the building is the follows:

Building has a regular plan $(40 \mathrm{~m} \times 25 \mathrm{~m})$ as shown in Figure 3.1.each building contains 12 floors and the height of the building (42) meters The structural system is select as concrete frames with identical columns of $50 / 50$ centimeters in size, and beams of dimension 50/30 centimeters. Each floor slab has 16 centimeters thickness and the story height is 3.5 meters.

\begin{tabular}{|l|l|}
\hline Hight of each storey & $\mathbf{3 . 5} \mathbf{~ m}$ \\
\hline Number of storey & Twelve $(\mathbf{G}+\mathbf{1 1})$ \\
\hline Shear wall thickness & $\mathbf{2 5 0} \mathbf{~ m m}$ \\
\hline Grade of concrete and steel & $\mathbf{M 2 0}$ and Fe $\mathbf{4 1 5}$ \\
\hline Size of beam & $\mathbf{5 0 0} \times \mathbf{3 0 0} \mathbf{~ m m}^{\mathbf{2}}$ \\
\hline Size of column & $\mathbf{5 0 0} \mathbf{5 0 0} \mathbf{~ m m}^{2}$ \\
\hline location & Baghdad \\
\hline
\end{tabular}




\section{3 - Deflection Diagram}

Table 3-1

\begin{tabular}{|c|c|c|}
\hline \multicolumn{2}{|c|}{ Building with shear wall } & Shear force \\
\hline Storey Numbers & Bending moment & 23.483 \\
\hline Storey12 & 14.274 & 25.717 \\
\hline Storey11 & 19.303 & 25.541 \\
\hline Storey10 & 18.873 & 25.627 \\
\hline Storey9 & 19.049 & 25.697 \\
\hline Storey8 & 19.152 & 25.792 \\
\hline Storey7 & 19.285 & 25.911 \\
\hline Storey6 & 19.449 & 26.054 \\
\hline Storey5 & 19.646 & 26.219 \\
\hline Storey4 & 19.876 & 26.400 \\
\hline Storey3 & 20.104 & $\mathbf{2 6 . 5 8 2}$ \\
\hline Storey2 & 20.393 & $\mathbf{2 6 . 5 8 6}$ \\
\hline Storey1 & 19.524 &
\end{tabular}

Table 3-2

\begin{tabular}{|c|c|c|}
\hline & Building without shear wall \\
\hline Storey Numbers & Shear force & Bending moment \\
\hline Storey12 & 29.824 & $\mathbf{2 6 . 4 7 8}$ \\
\hline Storey11 & 32.221 & 33.985 \\
\hline Storey10 & 32.076 & 33.380 \\
\hline Storey9 & 31.845 & 32.835 \\
\hline Storey8 & 31.573 & 32.147 \\
\hline Storey7 & 31.239 & 31.312 \\
\hline Storey6 & 30.836 & 30.302 \\
\hline Storey5 & 30.360 & 29.112 \\
\hline Storey4 & 29.811 & 27.737 \\
\hline Storey3 & 29.181 & 26.157 \\
\hline Storey2 & 28.456 & 24.372 \\
\hline Storey1 & 27.549 & 21.913 \\
\hline
\end{tabular}

Table 3.3

\begin{tabular}{|c|c|c|c|}
\hline Storey Numbers & $\begin{array}{l}\text { Displacement } \\
\text { of } 12 \text { storey } \\
\text { building without } \\
\text { shear wall } \\
(\mathrm{mm})\end{array}$ & Storey Numbers & $\begin{array}{l}\text { Displacement } \\
\text { of } 12 \text { storey building } \\
\text { with shear wall } \\
(\mathrm{mm})\end{array}$ \\
\hline Storey 12 & 6.428 & Storey12 & 2.183 \\
\hline Storey11 & 6.359 & Storey11 & 2.185 \\
\hline Storey10 & 6.204 & Storey10 & 2.143 \\
\hline Storey9 & 5.966 & Storey9 & 2.084 \\
\hline Storey8 & 5.647 & Storey8 & 2.002 \\
\hline Storey7 & 5.248 & Storey7 & 1.899 \\
\hline Storey6 & 4.768 & Storey6 & 1.776 \\
\hline Storey5 & 4.206 & Storey5 & 1.634 \\
\hline Storey4 & 3.571 & Storey4 & 1.471 \\
\hline Storey3 & 2.857 & Storey3 & 1.290 \\
\hline Storey2 & 2.074 & Storey2 & 1.078 \\
\hline Storey1 & 1.225 & Storey1 & 0.839 \\
\hline
\end{tabular}




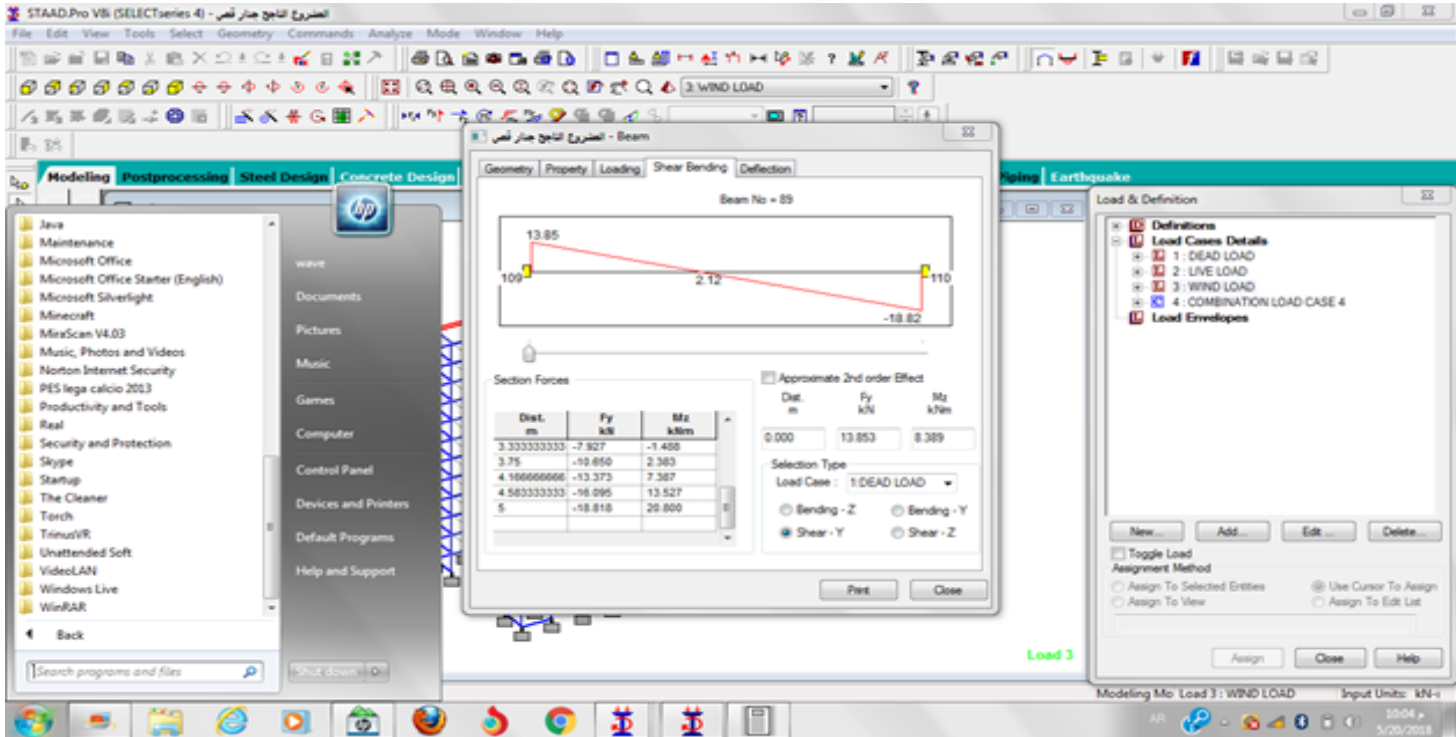

Figure. 3.1 Buildings with Shear Wall (shear bending)

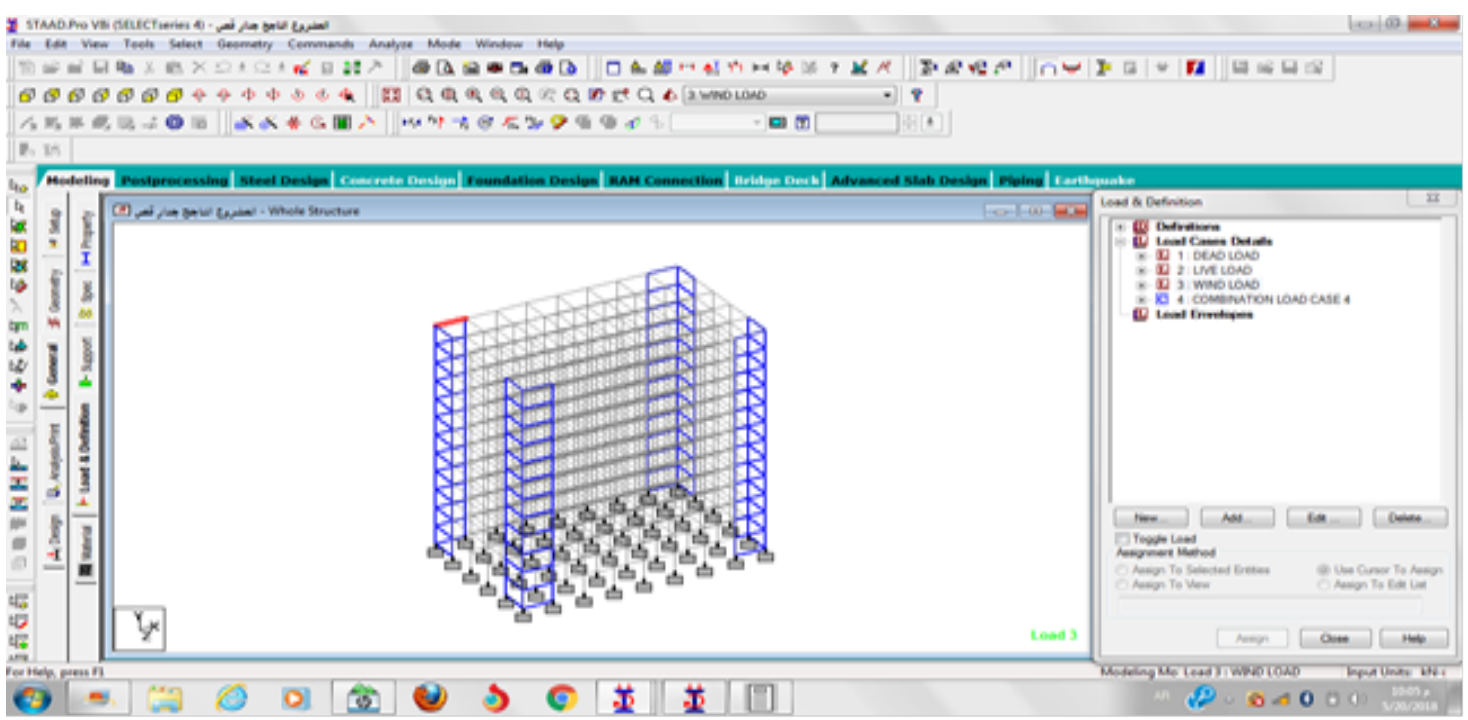

Figure. 3.2 Buildings with Shear Wall

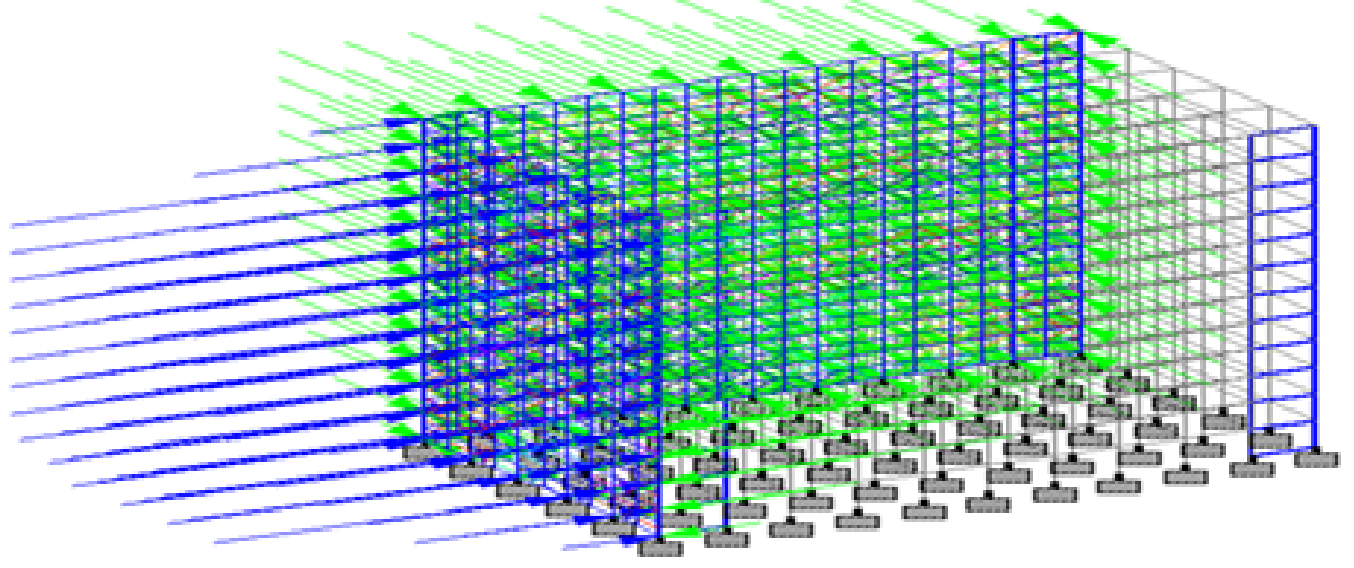

Figure .3.3 wind load applied to the shear wall building 


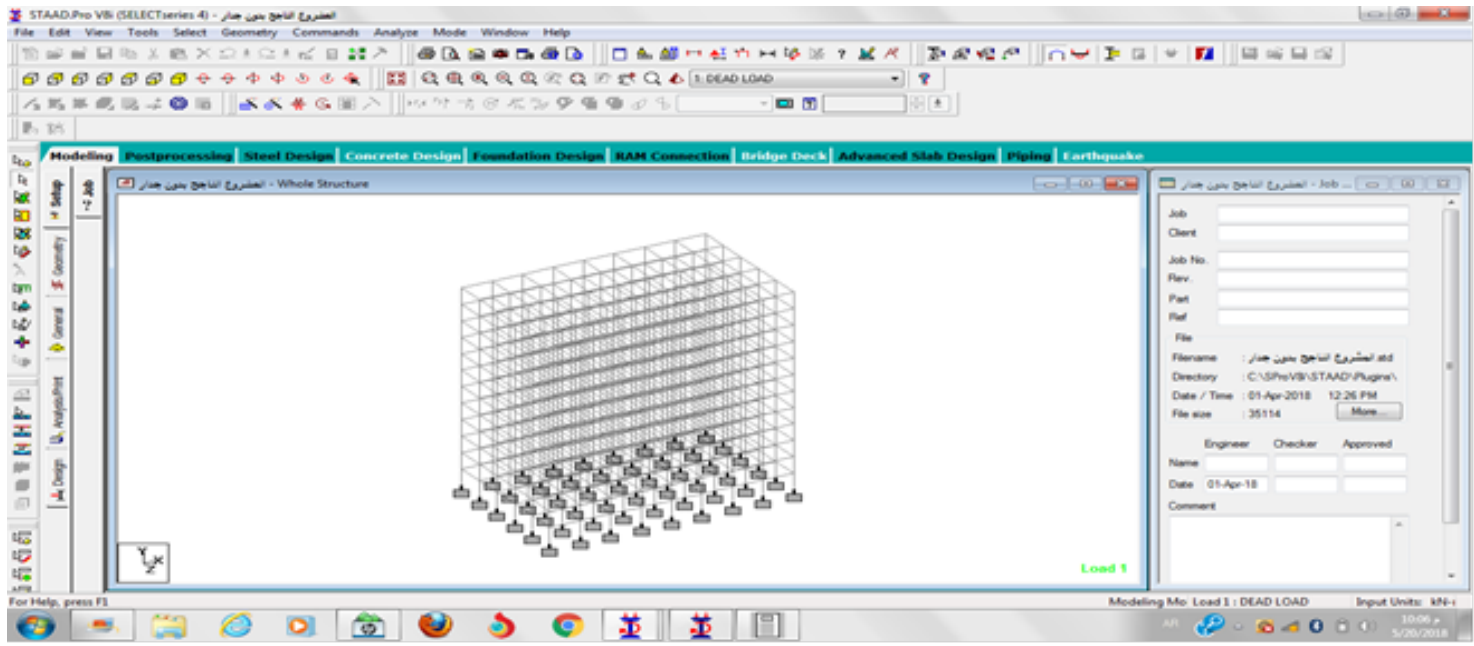

Figure 3.4 Building without shear wall

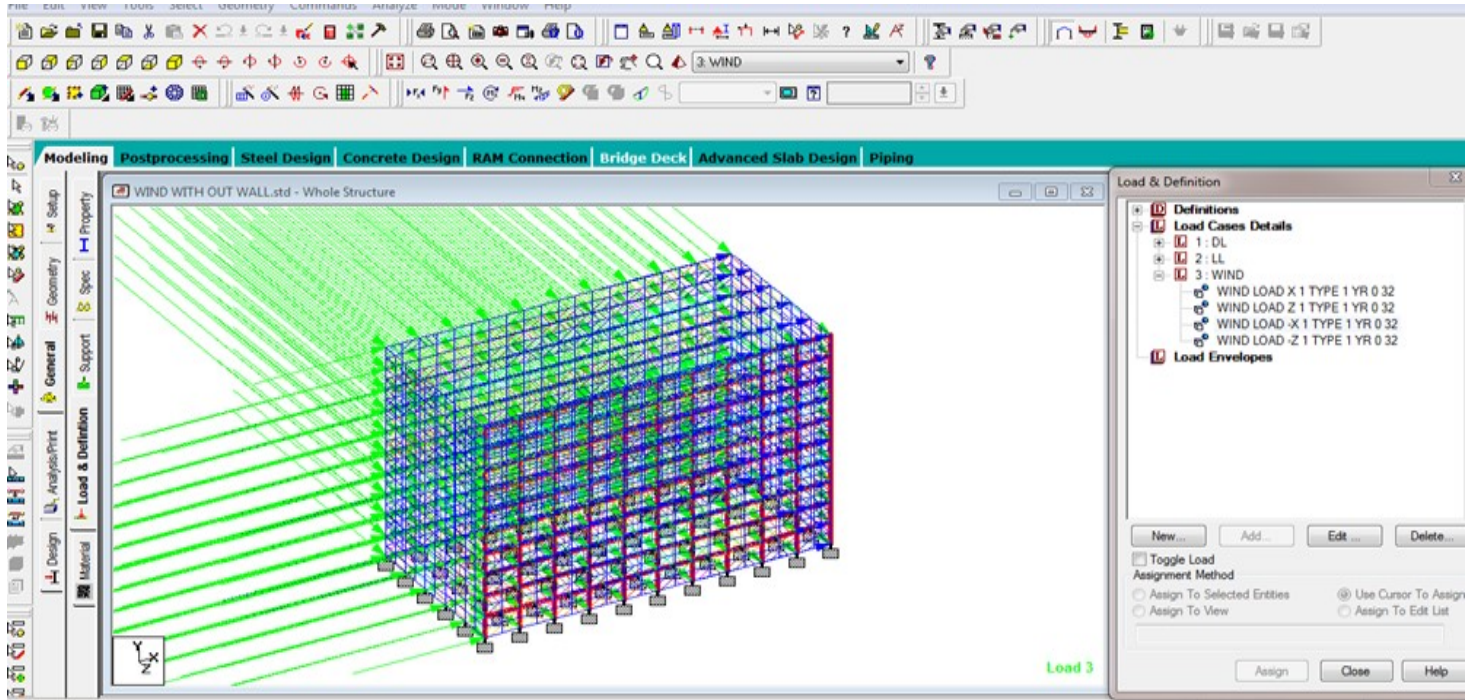

Figure 3.5 wind load applied without shear wall building

\section{4 - Result and Discussion}

- Comparison between displacement of 12 storey building without shear wall and with shear wall at each floor level are shown in table 3.3

- Comparison between Shear force of 12 storey building without shear wall and with shear wall at each floor level are shown in table 3.1 and table 3.2

- Comparison between Bending moment displacement of 12 storey building without shear wall and with shear wall at each floor level are shown in table 3.1 and table 3.2

\section{Conclusion}

After the results showed us, grasp the extent of the impact of the shear wall on the building, and facilitate them to resist the momentum and shear forces that come back from the impact of wind on the building. We found it important and really important to use the shear in close high buildings, particularly in areas with high winds and hurricanes, as a result of this prevents the incidence of fabric and human losses within the buildings.

\section{References}

1. Structural Concrete theory And Design Fifth Edition M.Nadim Hassoun South Dakota State University Akthem Al-Manaseer.

2. Design Of Concrete Structures Fourteenth Edition Nilson .

3. Reinforced Concrete Design Of tall Buildings Bungales.

4. Foundation Analysis And Design Fifth Edition Joseph E.Bowles , Re., S.E.

5. Building And Environment M. Halis Gunel, H. Emre Ilgin.

6. Website. 